\title{
Kewajiban Menjaga Kerahasiaan Dalam Pembuatan Akta Bagi Calon Notaris Magang
}

\section{Anggun Ludy Hardani}

Program Magister Kenotariatan Fakultas Hukum Universitas Islam Indonesia Yogyakarta Indonesia Jln.Cik Ditiro No. 1 Yogyakarta Indonesia pascahukum@uii.ac.id

\begin{tabular}{ll}
\hline Key Word: & Abstract \\
Deed; obligation; & There are two formulations of the problem in this study: first, what are the \\
prospective notary; & obligations of prospective notary apprentices in a notary office? Second, how can \\
secret & the sanctions for violating Article 16 of Law Number 2 of 2014 on Notary Positions \\
& be applied to prospective notary apprentices? This study uses a normative juridical \\
& approach. By reviewing a statutory regulation as a basis for solving problems. \\
& Research data were collected by interviewing notaries and prospective notaries who \\
& had carried out their internship obligations, as well as reviewing laws and \\
& regulations, books and other documents related to research. The results of this \\
& research are that the obligations of prospective notary apprentices have been well- \\
& stated in the law; and prospective notary apprentices who violate the obligation to \\
& keep the deed a secret cannot be equated with sanctions imposed on notaries.
\end{tabular}

\begin{tabular}{ll}
\hline Kata-kata Kunci: & Abstrak \\
\cline { 2 - 3 } Akta; calon notaris; & Terdapat dua rumusan masalah dalam penelitian ini: pertama, apakah \\
kerahasiaan; & kewajiban calon notaris magang di kantor notaris? Kedua, bagaimana sanksi \\
kewajiban & terhadap pelanggaran Pasal 16 Undang-Undang Nomor 2 Tahun 2014 \\
& tentang Jabatan Notaris dapat diterapkan pada calon notaris magang? \\
& Penelitian ini menggunakan pendekatan yuridis normatif. Dengan \\
& mengkaji suatu peraturan perundang-undangan sebagai dasar dalam \\
& melakukan pemecahan masalah. Data penelitian dikumpulkan dengan cara \\
& wawancara kepada notaris dan calon notaris yang telah melaksanakan \\
& kewajiban magang, serta mengkaji peraturan undang-undangan, buku \\
& pustaka maupun dokumen lainnya yang berkaitan dengan penelitian. Hasil \\
& dari penelitian ini bahwa kewajiban calon notaris magang adalah apa yang \\
& ada dalam undang-undang. Calon notaris magang yang melanggar \\
& kewajiban merahasiakan akta tidak dapat dipersamakan dengan sanksi \\
& yang dikenakan kepada notaris.
\end{tabular}

\section{Pendahuluan}

Notaris merupakan pejabat umum yang diangkat dan diberhentikan oleh Menteri Hukum dan Hak Asasi Manusia dan berwenang membuat akta autentik. Notaris sebelum diangkat memiliki status sebagai calon notaris dan menurut Pasal 16 ayat (1) huruf n Undang-Undang Nomor 30 Tahun 2004 tentang Jabatan Notaris sebagaimana telah diubah dengan Undang-Undang 2 Tahun 2014 (selanjutnya disebut UUJN) diwajibkan untuk magang di kantor notaris. Sanksi yang dapat diberikan kepada notaris yang menolak magang calon notaris termuat secara jelas dalam Pasal 16 ayat (13) UUJN yang menegaskan bahwa notaris dapat dikenai sanksi berupa peringatan tertulis. Perlunya proses magang bagi calon notaris adalah untuk memperoleh pengetahuan hukum, seperti dalam membuat akta autentik yang sah dan memberi penyuluhan 
hukum kepada masyarakat awam terkait pembuatan, pengadaan, serta hal lainnya seputar akta. ${ }^{1}$

Notaris dalam menjalankan profesinya terikat dengan ketentuan undang-undang dan kode etik profesi notaris sebagai amanah dari undang-undang. ${ }^{2}$ Contohnya seperti dalam membuat akta, harus selalu berpedoman pada ketentuan peraturan perundangundangan yang berlaku yaitu UUJN dan juga Kode Etik Notaris. Akta-akta yang dibuat oleh notaris merupakan akta autentik yang dapat digunakan sebagai alat bukti yang mempunyai kekuatan pembuktian sempurna. ${ }^{3}$ Akta autentik yang merupakan alat bukti tertulis terkuat dan terpenuh memberi sumbangan nyata bagi penyelesaian perkara secara murah dan cepat. ${ }^{4}$ Akta autentik biasanya dibuat dalam bentuk perjanjian, berkaitan dengan perjanjian yang dibuat oleh anggota masyarakat. ${ }^{5}$

Seorang notaris bertanggung jawab untuk melaksanakan kepercayaan pelanggan dengan sebaik-baiknya dan apabila kepercayaan itu dilanggar di dalam membuat akta baik yang disengaja maupun yang tidak disengaja maka notaris wajib mempertanggungjawabkannya. ${ }^{6}$ Pengawasan terhadap pelaksanaan kode etik notaris dilakukan oleh Dewan Kehormatan Notaris sedangkan pengawasan di dalam UUJN oleh Majelis Pengawas Notaris. ${ }^{7}$

Notaris dalam menjalankan perintah tugas jabatannya, wajib melakukan sesuai dengan isi sumpah pada waktu hendak memangku jabatan Notaris. Batasan seorang notaris dikatakan mengabaikan tugas atau kewajiban jabatan, apabila notaris tidak melakukan perintah imperatif undang-undang yang dibebankan kepadanya. ${ }^{8}$ Pasal 4 UUJN mengatur tentang sumpah dan janji Notaris dan Pasal 16 ayat (1) huruf (f) UUJN, dalam pembuatan akta notaris wajib untuk menjaga kerahasiaan segala sesuatu mengenai akta yang dibuatnya dan segala keterangan yang diperoleh guna pembuatan akta sesuai dengan sumpah janji jabatan kecuali undang-undang menentukan lain. ${ }^{9}$

Calon notaris adalah orang yang magang di kantor notaris setelah lulus dari Magister Kenotariatan. Kewajiban calon notaris yang magang diatur dalam Pasal 16A UUJN, yaitu:10

\footnotetext{
1 Yanti Jacline Jennier Tobing, "Pengawasan Majelis Pengawas Notaris dalam Pelanggaran Jabatan dan Kode Etik Notaris", Jurnal Media Hukum, 2010, hlm. 23.

${ }^{2}$ M. Agus Santoso, Hukum, Moral, dan Keadilan : Sebuah Kajian Filsafat Hukum, Edisi Pertama, Kencana, Jakarta, 2012, hlm. 113.

${ }^{3}$ Santia Dewi dan R.M Fauwas Diradja, Panduan Teori dan Praktik Notaris, Pustaka Yustika, Yogyakarta, 2011, hlm. 36.

${ }^{4}$ Henny Saida Flora, "Tanggung Jawab Notaris Pengganti dalam Pembuatan Akta", Kanun Jurnal Ilmu Hukum, XIV, Agustus 2012, hlm. 180.

${ }^{5}$ Hairus, "Peran Organisasi Profesi Notaris dalam Menjaga Martabat Profesi Notaris", Jurnal Hukum dan Kenotariatan II, Februari, 2018, hlm. 153.

${ }^{6}$ Edwar, et. al., "Kedudukan Notaris sebagai Pejabat Umum Ditinjau dari Konsep Equality Before The Law”, Jurnal Hukum dan Pembangunan I, Januari-Maret, 2019, hlm. 184.

${ }^{7}$ Ibid

8 Abdul Ghofur Anshori, Lembaga Kenotariatan Indonesia Perspektif Hukum dan Etika, UII Press, Yogyakarta, 2009, hlm. 177.

${ }_{9}$ Peasetya Agung Laksana, "Batas-Batas Kewajiban Menjaga Kerahasiaan Notaris dalam Kaitannya Hak Ingkar Notaris Berdasarkan Undang-Undang Tentang Jabatan Notaris”, Jurnal Akta Vol. 3, Desember 2016, hlm. 2 .

10 Undang-Undang Nomor 2 Tahun 2014 tentang Jabatan Notaris
} 
(1)Calon Notaris yang sedang melakukan magang wajib melaksanakan ketentuan sebagaimana dimaksud dalam Pasal 16 ayat (1) huruf a.

(2)Selain kewajiban sebagaimana dimaksud pada ayat (1), calon Notaris juga wajib merahasiakan segala sesuatu mengenai Akta yang dibuatnya dan segala keterangan yang diperoleh guna pembuatan akta.

Kewajiban notaris menurut Pasal 16 ayat (1) huruf a yaitu "Bertindak jujur, seksama, mandiri, tidak berpihak dan menjaga kepentingan pihak yang terkait dalam perbuatan hukum."11 Dalam pasal ini sudah jelas bahwa sebagai seorang notaris diharapkan dapat bertindak jujur, seksama, mandiri, tidak berpihak dan menjaga kepentingan pihak yang terkait dalam perbuatan hukum. Notaris juga diwajibkan untuk merahasiakan segala hal yang berhubungan dengan jabatannya sebagai pejabat publik, sebagaimana juga telah diatur dalam UUJN. Calon notaris yang sedang magang belum diangkat sebagai pejabat notaris yang telah diambil sumpah dan janjinya, tetapi secara tidak langsung calon notaris yang sedang magang juga membantu dalam praktek membuat akta di tempat magang, oleh karenanya seorang calon notaris juga harus bertindak jujur dan tidak memihak di tempat ia magang.

Kewenangan pembuatan akta oleh notaris terdapat dalam Pasal 1 ayat (1) dan 15 ayat (1) UUJN. Sementara, ketentuan sanksi bagi seorang notaris yang melanggar ketentuan Pasal 16 ayat (1) huruf a sampai dengan i sudah dijelaskan dalam Pasal 16 ayat (11) UUJN, namun dalam UUJN, justru tidak mengatur pemberian sanksi yang tegas terhadap calon Notaris, apabila calon notaris magang tidak dapat melakukan kewajibannya sesuai dengan peraturan yang ada.

Dengan adanya ketentuan Pasal 15 ayat (1) UUJN mengenai kewenangan notaris membuat akta autentik, maka menimbulkan permasalahan dengan ketentuan Pasal $16 \mathrm{~A}$ ayat (2) UUJN bahwa calon notaris wajib merahasiakan segala sesuatu mengenai draft akta yang dibuatnya. Dilihat dari pasal tersebut dapat diartikan bahwa calon notaris magang juga mempunyai kewanangan untuk membuat akta, padahal calon notaris yang sedang magang itu belum diangkat sebagai pejabat notaris yang telah diambil sumpah dan janjinya. Ketidaksesuaian antara pasal tersebut menimbulkan permasalahan terkait kewajiban calon notaris magang untuk merahasiakan segala sesuatu mengenai akta yang dibuatnya, bagaimana keabsahan dari akta tersebut serta bagaimana penerapan sanksi apabila melanggar Pasal 16 UUJN bagi calon notaris magang.

\section{Rumusan Masalah}

Berdasarkan latar belakang masalah di atas, permasalahan penelitian ini adalah, pertama, apakah kewajiban calon notaris magang di kantor notaris? Kedua, bagaimana sanksi terhadap pelanggaran Pasal 16 Undang-Undang Jabatan Notaris dapat diterapkan pada calon notaris magang? 


\section{Tujuan Penelitian}

Tujuan dari penelitian ini adalah perytama, untuk mengetahui tanggung jawab calon notaris magang terkait kewajiban calon notaris yang magang di kantor notaris. Kedua, kesesuaian sanksi yang dijatuhkan dengan peraturan perundang-undangan yang berlaku.

\section{Metode Penelitian}

Penelitian ini termasuk ke dalam penelitian hukum normatif dengan menggunakan pendekatan perundang-undangan (statute approach) dan pendekatan kasus (case approach). Bahan hukum yang digunakan dalam penelitian ini meliputi bahan hukum primer, bahan hukum sekunder dan bahan hukum tersier. Bahan hukum primer meliputi Undang-Undang No. 2 Tahun 2014 tentang Jabatan Notaris, Peraturan Perkumpulan Ikatan Notaris Indonesia (INI), dan Kode Etik Notaris. Bahan hukum sekunder berupa buku, dokumen, jurnal hukum, doktrin dan khususnya peraturan perundang-undangan yang terkait dengan permasalahan yang dikaji yaitu mengenai kewajiban Notaris. Bahan hukum tersier yang digunakan berupa kamus untuk memahami kata- kata yang kurang jelas dalam istilah hukum maupun istilah lain.

Metode yang digunakan dalam pengumpulan bahan hukum yaitu studi pustaka berupa penelusuran dengan mempelajari bahan bacaan berupa buku-buku yang dijadikan referensi dan literatur yang terkait kewajiban calon notaris magang guna memperoleh teori-teori dan informasi yang dibutuhkan. Studi dokumen, merupakan teknik pengumpulan data yang tidak langsung ditujukan kepada subjek penelitian. Teknik analisis yang digunakan terhadap bahan-bahan hukum yang telah terkumpul untuk menyelesaikan permasalahan yang diangkat dalam penelitian ini adalah dilakukan dengan metode analisis deskriptif.

\section{Hasil Penelitian dan Pembahasan}

Notaris berlandaskan pada nilai moral, sehingga pekerjaannya harus berdasarkan kewajiban, yaitu ada kemauan baik pada dirinya sendiri, tidak bergantung pada tujuan atau hasil yang dicapai. Notaris sangat membutuhkan moral dan hukum yang tak terpisahkan agar dapat menjalankan tugas profesinya secara profesional tanpa cela dari masyarakat. ${ }^{12}$ Berdasarkan penjelasan tersebut, maka perlu adanya kesadaran berkewajiban untuk menjunjung tinggi etika profesi, menjaga martabat dalam mempraktikkan profesi, yaitu bekerja bukan untuk mencari keuntungan melainkan mengabdi kepada sesama.

Salah satu kewajiban notaris adalah menerima magang. Jadi apabila ia menolak magang bisa jadi kesalahan notaris. Namun notaris juga bisa menolak pengajuan calon notaris yang ingin magang di kantornya apabila dengan alasan yang jelas, misalnya ruangan kantor yang sudah tidak dapat menampung karena sudah terlalu banyak calon

12 Evie Murniaty, "Tanggung Jawab Notaris dalam Hal Terjadi Pelanggaran Kode Etik", Tesis Program Pascasarjana Universitas Diponegoro, Semarang, 2010, hlm. 4. 
notaris magang. Setiap notaris mempunyai cara sendiri-sendiri untuk membimbing calon notaris yang sedang magang.

Kewajiban calon notaris magang adalah apa yang ada dalam undang-undang, akan tetapi hak-hak maupun kewenangan calon notaris pada saat magang tidak ditentukan dalam undang-undang. Hak-hak calon notaris diperoleh hanya dari perkumpulan atau organisasi notaris sepanjang calon notaris tersebut telah tercatat sebagai Anggota Luar Biasa.

Dalam UUJN terdapat tambahan pasal mengenai kewajiban bagi calon notaris, yaitu Pasal 16A yaitu:

(1) Calon Notaris yang sedang melakukan magang wajib melaksanakan ketentuan sebagaimana dimaksud dalam Pasal 16 ayat (1) huruf a.

(2) Selain kewajiban sebagaimana dimaksud pada ayat (1), calon Notaris juga wajib merahasiakan segala sesuatu mengenai Akta yang dibuatnya dan segala keterangan yang diperoleh guna pembuatan Akta."

Dilihat dari ketentuan Pasal 16A ayat (1) yang menjelaskan bahwa calon notaris yang sedang melakukan magang wajib melaksanakan ketentuan sebagaimana dimaksud dalam Pasal 16 ayat (1) huruf a, maka artinya calon notaris yang sedang magang juga harus melakukan sebagaimana kewajiban notaris untuk bertindak amanah, jujur, saksama, mandiri, tidak berpihak, dan menjaga kepentingan pihak yang terkait dalam perbuatan hukum. Hal itu adalah dasar karakter seorang pejabat notaris.

Calon notaris adalah orang yang magang di kantor notaris setelah lulus dari Magister Kenotariatan, jadi kewajiban calon notaris sebenarnya tidak dapat disamakan dengan kewajiban notaris dalam Pasal 16 ayat 1 huruf a tersebut. Notaris sebagai pejabat umum memperoleh wewenang secara atribusi, karena wewenang tersebut diberikan oleh UUJN sendiri. Calon notaris jika dilihat dari Pasal 16A ayat (2), maka wewenangnya adalah wewenang atribusi. Kewenangan atributif yaitu kewenangan yang berasal dari pembagian kekuasaan negara oleh Undang-Undang Dasar Tahun 1945 (UUD 1945) dan undang-undang kepada suatu lembaga negara/pemerintahan.

Namun setelah dipelajari, makna Pasal 16A ayat (2) sebenarnya yaitu bahwa calon notaris hanya berwenang membuat draft akta ataupun belajar akta-akta yang dibuat oleh notaris, dengan demikian maka artinya calon notaris yang sedang magang tidak memiliki kewenangan untuk membuat dan mengesahkan akta. Hal itu adalah kesempatan yang diberikan oleh notaris kepada calon notaris untuk belajar mengenai pembuatan draf akta dan yang mengesahkan/menandatangani akta tersebut tetaplah notaris itu sendiri.

Berdasarkan hasil wawancara dengan Notaris Mustofa13, berpendapat bahwa produk akta itu dihasilkan oleh notaris dan menjadi tanggung jawab notaris bukan karyawan termasuk juga bukan calon notaris magang. Jadi bertindak jujur, seksama, amanah, hati-hati, tidak berpihak itu nanti saat sudah diangkat menjadi notaris, bukan dalam kapasitas sebagai calon. Dalam menjalankan jabatannya, notaris harus cermat, tidak boleh berbohong, juga tidak boleh memihak salah satu pihak. Hanya saja, calon

${ }^{13}$ Hasil wawancara, Kantor Notaris Mustofa Sabtu, 15 Agustus 2020, pukul 10.30 wib, Yogyakarta. 
notaris juga harus tetap dapat dipercaya jujur, amanah serta hati-hati ketika menjalankan pekerjaan yang ditugaskan kepadanya di kantor tempat ia magang misalnya terkait dengan transaksi-transaksi .

Dalam menjalani proses magang, calon notaris boleh mengikuti praktik yang terjadi di kantor tempat ia magang. Salah satu yang menjadi kesulitan saat menjalani magang seperti kendala yang terjadi di lapangan. Misalnya masalah ketika di Badan Pertanahan Nasional ada berkas yang kurang. ${ }^{14}$

Pembentukan peraturan perundang-undangan harus memperhatikan kepastian hukum dan tujuan yang jelas untuk menjamin kepastian, ketertiban, dan perlindungan hukum agar tidak menimbulkan kebingungan hukum. Kewenangan merupakan kekuasaan formal yang dimiliki oleh pejabat atau institusi. 15 Terkait dengan kewenangan seseorang dalam menjalankan jabatannya, maka kewenangan tersebut selalu diikuti dengan pertanggungjawaban setelah menjalankan kewenangan. ${ }^{16}$ Suatu tanggung jawab dibebankan kepada seseorang yang memiliki suatu wewenang untuk itu. Dalam hal ini, apa yang menjadi kewajiban maupun tanggung jawab notaris yang mempunyai kewenangan secara jelas ditentukan dalam undang-undang, tidak dapat dipersamakan dengan calon notaris yang tidak mempunyai kewenangan terkait hal itu.

Lebih lanjut dalam Pasal 16A ayat (2) UUJN disebutkan bahwa calon notaris juga wajib merahasiakan segala sesuatu mengenai akta yang dibuatnya dan segala keterangan yang diperoleh guna pembuatan akta. Dengan adanya ketentuan pasal tersebut bukan berarti calon notaris berwenang untuk membuat akta. Melainkan mengenai akta yang dibaca, diketahui maupun dipelajari olehnya.

Pasal 1868 Kitab Undang-Undang Hukum Perdata, yang dimaksud dengan akta autentik adalah suatu akta yang dibuat dalam bentuk yang ditentukan undang-undang oleh atau di hadapan pejabat umum yang berwenang untuk itu di tempat akta itu dibuat. ${ }^{17}$ Maka, suatu akta dapat dikatakan autentik apabila :

1. Dibuat dalam bentuk yang ditentukan oleh undang-undang;

2. Dibuat oleh atau di hadapan pejabat umum;

3. Akta yang dibuat oleh atau di hadapan Pejabat Umum yang berwenang untuk itu dan ditempat dimana akta itu dibuat.

Suatu akta yang dibuat oleh pejabat yang tidak memiliki wewenang dan tidak memenuhi syarat untuk membuatnya, maka tidak dapat dianggap sebagai akta autentik, akan tetapi mempunyai kekuatan sebagai akta di bawah tangan apabila ditandatangani oleh pihak-pihak yang bersangkutan. Hal tersebut sesuai dengan Pasal 1869 Kitab Undang-Undang Hukum Perdata yang menjelaskan bahwa suatu akta, yang karena tidak berkuasa atau tidak cakapnya pegawai termaksud di atas, atau karena suatu cacat dalam bentuknya, tidak dapat diberlakukan sebagai akta autentik, namun demikian mempunyai kekuatan sebagai tulisan di bawah tangan jika ditandatangani oleh para pihak.

\footnotetext{
${ }^{14}$ Hasil wawancara secara online, Resky Ramadhony Selasa, 18 Agustus 2020, pukul 12.24 wib.

15 Tengku Erwinsyahbana, Melinda, "Kewenangan dan Tanggung Jawab Notaris Pengganti setelah Pelaksanaan Tugas dan Jabatan Berakhir”, Lentera Hukum, V, 2018, hlm. 310.

${ }^{16}$ Ibid., hlm. 313.

${ }^{17}$ Kitab Undang-Undang Hukum Perdata
} 
Dari penjelasan tersebut di atas, dapat disimpulkan bahwa apabila suatu akta dibuat bukan notaris, termasuk jika notaris menggunakan Pasal 16A ayat (2) UUJN untuk mempercayakan pembuatan akta kepada calon notaris yang sedang magang, maka akta itu akan kehilangan keautentikannya.

Makna dari Pasal 16A ayat (2) UUJN itu adalah kalau calon notaris yang sedang magang mengetahui tentang isi suatu akta maka jangan disebar-sebarkan keluar, jangan diceritakan ke orang. Karena notaris di kantor tempat ia magang mempunyai kewajiban untuk tidak menyebarkan maka ia juga jangan melakukan dan turut merahasiakan segala sesuatu yang dirahasiakan.18

Kewajiban dan tanggung jawab calon notaris itu sebenarnya lebih mengenai kerahasiaan akta. Terkait tentang jujur, teliti, amanah, tidak berpihak itu bukan merupakan tanggung jawab calon notaris tetapi tanggung jawab notaris. Sedangkan arti dari kata "calon notaris magang wajib merahasiakan" itu bukan mengenai akta yang ia dibuat, tapi karena ia membantu, membaca ataupun belajar akta-akta yang dibuat oleh notaris tempat ia magang. ${ }^{19}$ Calon notaris boleh saja terlibat pada saat pembuatan akta, mengetik ataupun menjadi saksi dalam akta asalkan ia tetap menjaga kerahasiaan akta itu. Oleh karenanya, di dalam surat permohonan dan surat pernyataan disebutkan bahwa calon notaris magang harus merahasiakan akta-akta atau dokumen di kantor notaris tempat ia magang. ${ }^{20}$

Berdasarkan penjelasan diatas, maka calon notaris yang melakukan magang dikantor notaris tersebut hanya diberikan izin untuk berlatih membuat akta dari kliennya, tetapi nama dan tanda tangan tetaplah atas nama notaris yang bersangkutan bukan atas nama calon notaris magang tersebut karena calon notaris belum mempunyai kewenangan untuk membuat akta tetapi mempunyai hak untuk belajar atau berlatih dalam membuat akta.

Kejelasan dalam membuat peraturan perundangan, akan meminimalisir terjadinya multi tafsir, dengan kata lain undang-undang yang jelas memberikan kepastian hukum dan meminimalisir terjadinya sengketa. Kepastian hukum ialah keadaan dimana suatu peraturan dibuat dan diundangkan secara pasti karena mengatur secara jelas dan logis. Artinya, tidak terdapat kekaburan norma atau keraguan (multitafsir) dan logis dalam artian menjadi suatu sistem norma dengan norma lain sehingga tidak berbenturan atau menimbulkan konflik norma. ${ }^{21}$ Kepastian hukum menunjuk kepada pemberlakuan hukum yang jelas, tetap, konsisten dan konsekuen, yang pelaksanaannya tidak dapat dipengaruhi oleh keadaankeadaan yang sifatnya subjektif. Ketidaktaatan atau pelanggaran terhadap suatu kewajiban yang tercantum dalam aturan hukum mengakibatkan terjadinya ketidakaturan, maka perlu adanya sanksi bagi yang melanggar aturan maupun norma yang ada, agar menjadi kontrol terhadap kemungkinan adanya benturan kepentingan antar masyarakat, sehingga suatu negara dapat berjalan lebih teratur.

Apabila dikaji lebih mendalam, berkaitan dengan Pasal 16A UUJN tentang kewajiban calon notaris magang, tidak ditemukan pasal lain yang mengatur mengenai

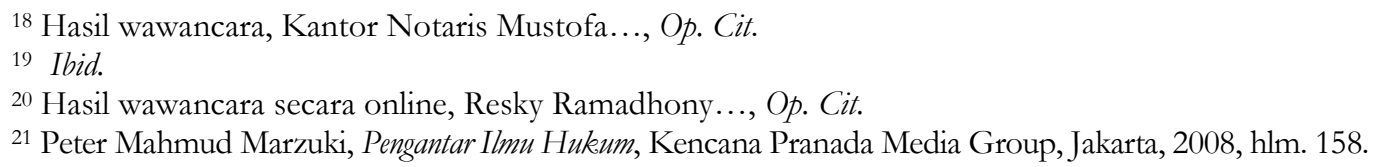


sanksi apabia ia melanggar pasal tersebut. Artinya, Pasal 16A UUJN tidak memenuhi teori kepastian hukum. Karena Pasal 16A UUJN mengatur secara jelas kewajiban calon notaris magang namun sanksi bagi calon notaris magang apabila tidak melakukan kewajibannya tidak diatur dalam UUJN tersebut.

UUJN maupun Kode Etik Notaris tidak mempunyai keberlakuan sanksi yang mengikat secara yuridis kepada para calon notaris magang. Akibatnya, segala sanksi yang diatur di dalam ketentuan UUJN serta kode etik tidak dapat diberikan kepada calon notaris apabila calon notaris yang sedang magang tidak melakukan kewajibanya sebagaimana yang dimaksudkan dalam Pasal 16A UUJN.

Akibat hukum bagi calon notaris magang yang tidak melakukan kewajibanya sebagaimana yang diatur dalam Pasal 16A tidak berakibat dijatuhkanya sanksi sebagaimana yang dijatuhkan kepada notaris yang melanggar Pasal 16 UUJN dan kode etik. Melainkan tetap berlaku sanksi menurut ketentuan umum bahwa barang siapa merugikan orang lain bisa dituntut ganti rugi atau mengenai perbuatan melawan hukum, sesuai dengan apa yang ingin dituntut oleh pihak yang bersangkutan bias berupa sanksi perdata, pidana maupun ITE. Dan juga bisa berupa sanksi moral yang menyebabkan calon notaris magang itu kehilangan kepercayaan karena dianggap tidak dapat dipercaya.

Sanksi yang diberikan kepada notaris menurut UUJN tidak dapat diterapkan kepada calon notaris magang, karena ia belum diangkat menjadi notaris dan ia tidak ada kewenangan membuat akta. Karena ia belum menjadi notaris maka tidak bisa dilaporkan ke Majelis Pengawas Notaris, hanya bisa dilaporkan ke Ikatan Notaris karena ia sudah menjadi anggota luar biasa.

Apabila ternyata si calon notaris magang itu menyebarkan mengenai akta, maka itu adalah tanggung jawab calon notaris magang itu sendiri yang memang sudah dilarang untuk berbuat seperti itu. Sanksinya sesuai dengan apa yang ingin dilaporkan secara perdata ataupun pidana oleh pihak yang bersangkutan. Akan tetapi, notaris yang menerima magang juga bisa ikut dilaporkan karena tidak berhati-hati sehingga dapat dibaca orang lain. Namun dalam hal ini, notaris dapat berdalih bahwa ia mempunyai kewajiban untuk menerima magang dan tidak ada ketentuan bahwa magang itu tidak boleh membaca arsip karena sedang tahap belajar. ${ }^{22}$

Calon notaris magang yang membocorkan rahasia akta dapat dimintai pertanggung jawaban baik perdata maupun pidana oleh pihak yang merasa dirugikan. Seorang yang mempunyai kewajiban menyimpan rahasia dapat dikenakan pidana sesuai dengan Pasal 322 Kitab Undang-Undang Hukum Pidana apabila ia membocorkan rahasia yang dipercayakan kepadanya tersebut. Pasal 322 Kitab Undang-Undang Hukum Pidana menentukan bahwa "Barang siapa dengan sengaja membuka rahasia yang wajib disimpannya karena jabatan atau pencariannya, baik yang sekarang maupun yang dahulu, diancam dengan pidana penjara paling lama sembilan bulan atau pidana denda paling banyak sembilan ribu rupiah". Dalam hal ini, yang mempunyai kewajiban merahasiakan akta sesuai dengan ketentuan Pasal 16 ayat (1) huruf f Undang-Undang Jabatan Notaris adalah notaris. Apabila dikaitkan dengan teori tanggung jawab yang didasarkan atas kesalahan, calon notaris magang yang membocorkan rahasia akta atau

${ }^{22}$ Hasil wawancara, Kantor Notaris Mustofa..., Op. Cit. 
segala sesuatu yang berhubungan dengan akta, maka calon notaris yang bertanggung jawab atas kesalahannya. Namun dalam hal ini, yang mempunyai kewajiban merahasiakan akta karena jabatan atau pencariannya adalah notaris.

Calon notaris yang sedang magang juga dapat dikenai sanksi perdata apabila ada pihak yang merasa dirugikan, yaitu Pasal 1365 Kitab Undang-Undang Hukum Perdata. Perbuatan membocorkan rahasia akta oleh calon notaris yang sedang magang dapat dikategorikan sebagai suatu perbuatan melawan hukum seperti yang tercantum dalam Pasal 1365 Kitab Undang-Undang Hukum Perdata karena bertentangan dengan asas kepatutan, ketelitian, serta sikap hati-hati yang seharusnya dimiliki seseorang. Dengan demikian, calon notaris magang itu belum diangkat sebagai notaris, maka tidak ada kewenangan membuat akta. Sehingga, tidak bisa dikenakan sanksi sebagaimana yang dikenakan kepada Notaris yang melanggar ketentuan Pasal 16 UUJN.

\section{Penutup}

Berdasarkan uraian pembahasan di atas, dapat disimpulan bahwa, pertama, kewajiban calon notaris magang adalah apa yang ada dalam UUJN. Pada dasarnya, kewajiban calon notaris magang untuk bertindak jujur, seksama, amanah, hati-hati itu merupakan pengaplikasian dalam produk akta yang dihasilkan oleh notaris dan menjadi tanggung jawab notaris bukan calon notaris magang, sehingga kewajiban tersebut bagi calon notaris magang kurang tepat apabila dipersamakan. Kewajiban calon notaris magang ini lebih berkaitan dengan ketentuan tentang merahasiakan segala sesuatu mengenai akta. Namun, artinya bukan akta yang ia buat sendiri, melainkan karena ia membantu membuat draft akta ataupun belajar akta-akta yang dibuat oleh notaris tempat ia magang.

Kedua, sanksi bagi calon notaris magang tidak ditentukan dalam UUJN sehingga dapat dikatakan tidak memberikan kepastian hukum karena tidak adanya keberlakuan sanksi yang mengikat secara yuridis kepada para calon notaris magang. Sanksi lain dapat dikenakan berupa sanksi moral kepada calon notaris magang yang tidak menjaga kerahasiaan mengenai akta yang dibuat oleh notaris di tempat ia magang. Selain itu, dapat berlaku sanksi hukum pidana karena perbuatan melawan hukum dan juga dapat dikenai sanksi perdata, apabila ada pihak yang merasa dirugikan.

Penulis memberikan saran bahwa perlu dijelaskan terkait hak dan kewenangan notaris terhadap calon notaris magang, ketegasan pengaturan yang lebih rinci terhadap setiap perbuatan yang mengatur calon notaris dalam melaksanakan magang, dan penambahan ketentuan sanksi bagi calon notaris magang yang membocorkan rahasia agar ada kejelasan dan kepastian hukum mengenai sanksi yang akan diterima calon notaris magang yang melanggar ketentuan.

\section{Daftar Pustaka}

\section{Buku}

Anshori, Abdul Ghofur, Lembaga Kenotariatan Indonesia Perspektif Hukum dan Etika, UII Press, Yogyakarta, 2009. 
Santoso, M. Agus, Hukum, Moral, dan Keadilan: Sebuah Kajian Filsafat Hukum, Edisi Pertama, Kencana, Jakarta, 2012.

Dewi, Santia dan Diradja, R,M Fauwas, Panduan Teori dan Praktik Notaris, Pustaka Yustika, Yogyakarta, 2010.

Soekanto, Soerjono, Pengantar Penelitian Hukum, Cetakan Ketiga, Universitas Indonesia, Jakarta, 2010.

\section{Jurnal}

Edwar, et. al., "Kedudukan Notaris Sebagai Pejabat Umum Ditijau dari Konsep Equality Before The Law", Jurnal Hukum dan Pambangunan, I, Januari-Maret, 2019.

Hairus, "Peran Organisasi Profesi Notaris dalam Menjaga Martabat Profesi Notaris", Jurnal Hukum dan Kenotariatan. I, Februari, 2018.

Henny Saida Flora, "Tanggung Jawab Notaris Pengganti dalam Pembuatan Akta" Kanun Jurnal Ilmu Hukum, XIV, Agustus, 2012.

Prasetya Agung Laksana, “Batas-Batas Kewajiban Menjaga Kerahasiaan Notaris dalam Kaitannya Hak Ingkar Notaris Berdasarkan Undang-Undang Tentang Jabatan Notaris", Jurnal Akta, Vol 3, Desember, 2016.

Tengku Erwinsyahbana, Melinda, "Kewenangan dan Tanggung Jawab Notaris Pengganti Setelah Pelaksanaan Tugas dan Jabatan Berakhir", Lentera Hukum. V, 2018.

Yanti Jacline Jennier Tobing, "Pengawasan Majelis Pengawas Notaris dalam Pelanggaran Jabatan dan Kode Etik Notaris", Jurnal Media Hukum, 2010.

\section{Tugas Akhir}

Evie Murniaty, "Tanggung Jawab Notaris dalam Hal Terjadi Pelanggaran Kode Etik", Tesis, Program Pascasarjana Universitas Diponegoro, Semarang, 2010.

\section{Peraturan Perundang-Undangan}

Undang-Undang Nomor 2 Tahun 2014 Tentang Perubahan Atas Undang-Undang Nomor 30 Tahun 2004 Tentang Jabatan Notaris, Lembaran Negara Republik Indonesia Tahun 2014, Tambahan Lembaran Negara RI Nomor 5491.

\section{Wawancara}

Hasil wawancara Kantor Notaris Mustofa Sabtu, 15 Agustus 2020, pukul 10.30 WIB, Yogyakarta.

Hasil wawancara secara online, Resky Ramadhony Selasa, 18 Agustus 2020, pukul 12.24 WIB. 